\title{
SEJARAH KEBUDAYAAN MODEL PEMBELAJARAN TRADISI \\ MAPPANRETASI DI DESA WIRITASI KELURAHAN PAGATAN \\ KECAMATAN HILIR KUSAN TANAH BUMBU TAHUN 2010-2020
}

\author{
Muhammad Rico \\ Email: 2010111210027@mhs.ulm.ac.id \\ Program Studi Pendidikan Sejarah Fakultas Keguruan dan Ilmu Pendidikan \\ Universitas Lambung Mangkurat \\ Banjarmasin
}

\begin{abstract}
Abstrak
Mappanretasi merupakan manifestasi rasa syukur masyarakat desa Wiritasi khususnya para Nelayan nya kepada Allah Swt akan hasil tangkapan ikan selama satu tahun. Kemudian dibalik setiap prosesi ritual tradisi ini (sebelum acara puncaknya Mappanretasi) juga mempunyai tujuan untuk memperoleh solidaritas sosial, menjalin silaturahmi antara warga, agar desa menjadi tentram, sejahtera, harmoni dengan menjaga dan merawat lingkungan hidup melalui cara-cara ritual-ritual keagamaan yang mengandung nilai-nilai kearifan lokal. dalam artikel ini juga ada beberapa kaitan mengenai metode konsep pembelajaran sejarah dimasa sekarang ini mengapa tradisi kebudayaan ini bisa semakin berkembang dan masih dipercayai oleh masyarakat suku Bugis yang bertempat tinggal dikabupaten tanah bumbu Kalimantan selatan banyak model pembelajaran dari sejarah kebudayaan nya makna pesan moral yang terkandung walau kadang banyak orang yang mempunyai persepsi negatif dalam tradisi ini dan beraanggapan sebuah tradisi yang sanggat menyimpang dan keluar dari pendidikan Islam sendiri proses pelaksanaan tradisi Manppanretasi (acara puncaknya) terlebih dahulu dimulai dengan beberapa rangkaian ritual adat yaitu, (a) mengadakan (musyawarah Mappanretasi), selanjutnya (b) ritual Maddemme Berre (merendam beras), (c)Mallibu Wanuwa (mengelilingi daerah), (d) Prosesi Adat di Panggung Adat, (e) syukuran dan selamatan di laut (acara puncak 'Mappanretasi) yang paling seru.
\end{abstract}

Kata Kunci : Model Pembelajaran, Sejarah Kebudayaan, Mappanretasi

\section{A. PENDAHULUAN}

Adapun seperti halnya di kalangan masyarakat Jawa dan etnis-etnis yang lainnya, khusunya di wilayah Kalimantan Selatan. Terdapat sebuah perkampungan kecil bernama desa Wiritasi tepatnya berada di Kelurahan Pagatan Kecamatan Kusan Hilir Kabupaten Tanah Bumbu, yang mana diketahui hingga saat ini desa tersebut 
masih mempertahankan tradisinya, yakni mereka menyebutnya dengan sebutan tradisi Mappan-retasi. Tradisi Mappanretasi, seperti halnya dengan tradisi yang lainnya terkadang masih dihubung-hubungkan dengan sesuatu yang mistis dan berbau sakral.

Tradisi ini diadakan setiap satu tahun sekali berbarengan dengan hari jadi Kabupaten Tanah Bumbu. Maka dari itu suasana sebelum puncak diadakannya tradisi Mappanretasi tepatnya menjelang minggu terakhir di bulan April berlangsung kemeriahan-kemeriahan dengan menampilkan berbagai macam perlombaan, pameranpameran berupa produk khas desa, seperti kuliner makanan ataupun berupa kerajinan tangan. Yang kesemuanya tersebut dapat menjadi sarana dalam mendorong perekonomian warga. Mengingat tradisi tersebut sudah dijadi- kan pengembangan wisata daerah atau aset kebudayaan wisata bahari etnis Bugis Tanah Bumbu yang masih bertahan hingga saat ini, dengan demikian seiring dikenalnya tradisi Mappanretasi dikalangan yang lebih luas besar harapannya membuat daerah Tanah Bumbu juga semakin dikenal tidak hanya pada budayanya saja akan tetapi juga kulinernya, kerajinan tangannya ataupun obyek-obyek wisata yang lainnya,dimana mereka akan tertarik untukmencoba dan membeli apa yang mereka inginkan entah itu berupa benda ataupun pengalaman yang menyenangkan untuk diceritakan.

Disamping itu kehidupan beragama masyarakat desa Wiritasi secara umum tergolong biasa-biasa saja. Artinya ada sebagian taat dan sebagian lagi tidak taat. Dari segi akhlak, tergolong rendah tingkat pengalamannya (menengah ke bawah). Sedangkan dari sisi syaria't, tergolong tingkat pengalaman menengah atas. Dengan demikian masyarakat tersebut dikategorikan masyarakat yang menjalankan ajaran agama, walaupun tidak secara keseluruhan (sempurna). Masyarakat desa Wiritasi yang memiliki sistem kekerabatan yang tinggi menyebabkan setiap kegiatan sosial dan agama dilakukan secara gotong royong dan tolong menolong. Mengenai yang dilakukan, benar dan salah tidak menjadi sorotan, orientasinya adalah keamanan dan keten- traman hidup masyarakat. Perbuatan benar dan salah tergantung dari baik atau buruknya tujuan dari perbuatan yang dilakukan.

sejarah adalah sebuah pembelajaran bukan warisan. Sebab warisan yang bekerja adalah yang mewariskan bukan yang diwariskan. Penerima warisan tidak bekerja, hanya penerima. Tidak jarang si penerima saling berebut warisan, bahkan 
menimbulkan konflik internal. Globalisasi merupakan sebutan era pada masa kini. Era kekinian juga memiliki sebutan lain yaitu masyarakat pasca kapitalis. Pengertian globalisasi dalam pandangan kebudayaan dapat dikatakan sebagai proses dunia yang sedang menjadi homogen. Homogen ditandai dengan semakin canggihnya media komunikasi sehingga memudahkan terjadinya mobilitas sosial dan intelektual secara intensif membuat batas-batas fisik negara dan budaya mengalami pencairan dan terintegrasi ke dalam tatanan globalisasi. Dampak globalisasi, hemat membuat kebudayaan nasional menjadi tidak relevan dan Miyoshia, multikulturalisme yang berkuasa pada masa kekinian (Renton, 2009: 4).

${ }^{1}$ Ali Muakhir, Ensiklopedia Pariwisata Indonesia "Festival-festival Meriah di Indonesia" (Jakarta: Progressio Publishing, tt), h. 143

\section{B. METODE PENELITIAN}

Penelitian ini membahas tentang Sejarah kebudayaan dalam tradisi Mappanretasi yang dikaitkan dengan beberapa jurnal yang relevan dengan materi dan studi kasus penulis sendiri dari Google scholar bapak Mohamad Zaenal Arifin Anis dan Ibu fitri mardiani serta membahasa sebuah studi kasus model pembelajaran Sejarah yang bertempat di desa Wiritasi Kelurahan Pagatan Kecamatan Kusan Hilir Kabupaten Tanah Bumbu. Penelitian ini bertujuan untuk mengetahui mengapa masyarakat desa Wiritasi melakukan tradisi Mappanretasi, bagaimana proses pelaksanaan tradisi Mappanretasi tersebut berjalan, dan nilai-nilai pembelajaran moral apa saja yang terkandung dalam tradisi Mappanretasi. Subjek dalam penelitian ini adalah semua komponen yang terlibat dalam tradisi Mappanretasi terutama pengurus Lembaga Ade' Ogi Tanah Bumbu (LAOTU) selaku yang berwenang dan bertanggungjawab dalam pelaksanaan tradisi tersebut. Sedang objek dalam penelitian ini adalah nilai-nilai pendidikan Islam dalam tradisi Mappanretasi. Teknik penggalian data, yang digunakan yaitu teknik observasi, wawancara, dan dokumentasi. Adapun teknik pengolahan data dilakukan dengan editing dan klasifikasi data. Selanjutnya dianalisis dengan analisa deskriftif kualitatif dan ditarik kesimpulan secara induktif serta ditambah dengan penelitian yang sudah ada terlebih dahulu dan dibedakan dengan ciri khas lebih dari yang sebelum nya.Berdasarkan hasil penelitian diketahui bahwa nilai- nilai pendidikan Islam dalam tradisi Mappanretasi di desa Writasi secara umum 
memang benar ada, hal ini dapat dilihat dari pengertian Mappanretasi dan proses pelaksanan tardisi Mappanretasi seperti ritual Mappammulagau Map-panretasi, Maddemme Berre, Mallibu Wanuwa, Prosesi Adat di Panggung Adat dimana kesemuanya tersebut meng- andung unsurunsur pendidikan Islam. Melalui tradisi ini membuktikan pula, bahwasanya pendidikan khususnya pendidikan Islam tidak mutlak diperoleh melalui lembaga formal saja namun bisa juga dari bentuk-bentuk yang menyimpan makna bagi kehidupan orang banyak sebagai- mana yang dilakukan masyarakat desa Wiritasi. Temuan penelitian ini menunjukkan setidaknya tradisi ini bisa menjadi solusi alternatif serta memberikan pengaruh positif kepada masyarakat terutama bagi pengembangan dan peningkatan pendidikan Islam.

\section{HASIL DAN PEMBAHASAN}

Sejarah menjadi aktual ketika diteliti dan dipelajari pada masa sekarang. Masalah yang kerap kali terjadi pada saat pembelajaran sejarah secara umum berlangsung ialah pembelajaran sejarah yang hanya sebatas pengetahuan, suatu kemampuan berpikir tingkat rendah. Padahal mestinya lebih dikembangkan kemampuan tingkat berpikir lebih tinggi, seperti menganalisis atau bahkan sampai mengevaluasi. Mengevaluasi itu dalam proses pembelajaran termasuk atribut berpikir kritis yang disebut pemberian pertimbangan. Dalam konteks belajar sejarah diperlukan pengembangan model pembelajaran yang harus mempertimbangkan sumber-sumber belajar dan yang mendukungnya. Dosen dan guru pengajar sejarah harus berupaya untuk menampung atau memperluas apreasiasi peserta didik terhadap sejarah yang harus dipelajari.

Terlepas dari pro kontra penilaian dari sudut pandang relegius, tradisi ini tiap tahunnya biasa digelar di pantai Pagatan (desa Wiritasi), Mappanretasi merupakan manifest- tasi rasa syukur dari masyarakat terhadap rezeki yang mereka dapatkan dari laut sebagai sumber mata pencaharian pokok masyarakat. Ritual Mappanretasi salah satunya ditan- dai dengan melepaskan beberapa sajian terbaik di laut lepas yang di antaranya berupa potongan kepala hewan ternak baik berupa kerbau, sapi, kambing dan juga ayam.

Berdasarkan kerangka berpikir diatas, penulis tertarikmencoba menuangkan dalam suatu penelitian guna menge- tahui maksud dan tujuan serta nilai-nilai pendidikan 
agama Islam pada tradisi Mappanretasi yang telah mentradisi dikalangan masyarakat desa Wiritasi. Dimana anggapan dari masyarakat Wiritasi dan sekitarnya yang mayoritasnya beragama Islam, bahwa pelaksanaan dari kegiatan tradisi Mappanretasi tersebut masih mengandung nilai-nilai pendi- dikan agama Islam. Oleh karena itu, penulis tertarik untuk melakukan penelitian secara lebih jauh dan mendalam tentang permasalahan ini dengan mengangkat judul "Nilai- Nilai Pendidikan Islam dalam Tradisi Mappanretasi Di Desa Wiritasi Kelurahan Pagatan Kecamatan Kusan Hilir Kabupaten Tanah Bumbu". Tujuan diadakannya tTradisi Mappanretasi merupakan salah satu tradisi etnis Bugis Tanah Bumbu yang masih bertahan hingga saat ini, khususnya bagi para Nelayan desa Wiritasi yang mana tradisi tersebut dilakukan demi mencapai ketentraman hidup lahir dan batin. Kehidupan ruhani etnis Bugis memang bersumber dari ajaran agama yang diberi hiasan budaya lokal. Oleh karena itu, orientasi kehidupan keberagamaan orang Bugis senantiasa memperhatikan nilai-nilai luhur yang telah diwariskan oleh nenek moyangnya. Seperti halnya dengan tradisi Mappanretasi yang senantiasa diadakan setiap satu tahun sekali oleh masyarakat desa Wiritasi.

Tradisi tersebut adalah turun temurun peninggalan dari nenek moyang leluhur. Sehingga tidak ada yang tahu bagaimana atau dari mana asal-usul adanya tradisi Mappan- retasi tersebut. Dari penuturan sesepuh adat sendiri tradisi ini sudah ada pada masa kolonial Belanda akan tetapi tidak ada catatan pasti kapan dan tahun berapa tradisi ini sudah dimulai, namun yang jelas tradisi ini dulunya dilaksanakan hanya secara sederhana tidak semeriah pada masa sekarang ini setelah melalui proses yang begitu panjang.

Masyarakat desa Wiritasi mengartikan bahwasanya tradisi Mappanretasi sama dengan acara Syukuran dan Sela- matan. Adapun pelaksanaan tradisi Mappanretasi pada masyarakat Wiritasi jatuh pada minggu terakhir di bulan April yang berlangsung selama satu hari. Dalam proses pelaksanaan tradisi Mappanretasi ini memang dilaksanakan dengan melibatkan banyak orang. Mereka melakukan ritual ini dengan dipimpin oleh para sesepuh masyarakat desa atau yang biasa mereka kenal dengan sesepuh adat seperti Sandro dan Pemangku adat yang lainnya Lembaga Ade' Ogi Tanah Bumbu (LAOTU) serta Pemerintahan. Tujuan dan pengaruh positif dengan dilaksanakannya tradisi Mappanretasi ini menumbuhkan rasa kesyukuran masyarakat 
kepada Allah Swt, sebagai pengatur dan pemberi rezeki bagi hamba- hambanya di dunia ini. Kemudian juga menumbuhkan semangat kegotong royongan antar sesama warga, ajang silaturahmi, kesadaran untuk merawat lingkungan demi menjadikan desa tersebut tentram, aman, sejahtera, dan makmur.

\section{${ }^{2}$ H. Machmudin, Kepadala Desa Wiritasi, Wawancara pribadi,Wiritasi, 15} Oktober 2020

3 Afifuddin dan Beni Ahmad Saebani, Metodologi Penelitian Kualitatif, (Bandung: Pustaka Setia, 2009), Cet ke-1, h. 131. Ibid, h. 175

Pengaruh negatif dilaksanakannya upacara tradisi Mappanretasi tersebut bahwasanya dalam agama Islam tidak pernah bahkan tidak ada ajaran ritual atau upacara tradisi Mappanretasi tersebut karena masih berbau mistik, akan tetapi tradisi tersebut sudah menjadi aset budaya di Indonesia terutama pada orang Bugis yang ada di Tanah Bumbu khususnya masyarakat Nelayan di desa Wiritasi yang mana mereka telah mempercayai dan melaksanakannya secara turun temurun. Dan masyarakat Bugis menganggap upacara tradisi ini juga berkaitan dengan lingkungan hidup. Sehingga banyak masyarakat yang mempercayai bahwa lingkungan hidup itu perlu dilestarikan dengan cara ritual- ritual atau mengadakan upacara tradisi atau adat keagamaan yang mengandung nilai-nilai kearifan lokal.

Dalam hal ini tradisi Mappanretasi merupakan wujud kebudayaan sebagai komplek aktivitas serta tindakan berpola dari manusia dalam masyarakat, seperti yang dikemukakan oleh Koentjaraningrat dalam Elly dkk., me- nyatakan bahwa wujud tersebut bersifat konkret sehingga dinamakan sistem sosial, karena menyangkut tindakan dan kelakuan berpola dari manusia itu sendiri yang dimana terdapat aktivitas manusia yang berinteraksi dan berhubung- an serta bergaul satu sama dengan yang lainnya dalam masyarakat. pembelajaran sejarah yang kritis dan bermuatan nilai-nilai Multikultural dapat di upayakan menggunakan model pembelajaran berfkir historis agar mengarahkan para generasi muda kepada tataran kesadaran yang mengantarkan mereka kembali menjadi Indonesia. Belajar sejarah dan mengetahui tentang sejarah bangsa ini bagi generasi muda akan menyadari bahwa sesungguhnya menjadi diri itu baik. 
Kemampuan mengkritisi setiap permasalahan hidup di era global dari nilai-nilai kehidupan yang dikandung dalam sejarah. Menjadi Indonesia dan kembali kepada identitas nasinal yang sesungguhnya merupakan sebuah keharusan. Kemampuan untuk dapat berpikir kritis tidak langsung dimiliki oleh setiap peserta didik namun harus melalui proses pembelajaran yang bersifat berkelanjutan. Membangun kembali identitas nasional bagi generasi muda dapat terbangun apabila peserta didik sering diajak melakukan keterampilan berpikir tingkat tinggi (mengkritisi). Salah satu cara yang paling efektif dengan menerapkan metode/model yang tepat khususnya dalam hal ini dilakukan dengan menggunakan model pembelajaran berpikir historis.

"Maddemme Berre" dalam ritual ini bagaimana caranya masyarakat dapat berpikir dan merenungi makna- makna yang terselip dari ritual ini termasuk sesajen yang nantinya akan dibagikan kepada masyarakat, artinya banyak hal yang dapat dijadikan pembelajaran melalui bentuk- bentuk ciptaan Allah Swt salah satunya adalah melalui sesajen-sesajen yang esensinya mengandung nilai-nilai luhuryang tidak bisa dilepaskan begitu saja hubungannya dengan kehidupan masyarakat khususnya masyarakat Bugis. Dengan timbulnya kesadaran seperti itu, yaitu hasil dari tafakkur, maka manusia akan pandai bersyukur terhadap nikmat- nikmat yang diberikan Allah kepada mereka. Sehingga segala apa yang diberikan, dapat digunakan dan dimanfaatkan sebagaimana mestinya.

Hal ini sebagaimana diperintahkan oleh Allah Swt kepada manusia, khususnya mereka yang berpengetahuan didalam surat Ali Imron ayat 190-191. Nilai-nilai pendidikan Islam yang terkandung dalam ritual ini termasuk dalam akidah, manusia meyakini dan menerima kebesaran Allah Swt sebagai Zat Mutlak yang Maha Esa melalui ciptaan-ciptaanya sehingga diharapkan mampu membentuk karakter manusia yang pandai bersyukur, bahwasanya manusia hanyalah makhluk yang lemah dan tidak berdaya bila tanpa adanya pertolongan Allah Swt dengan memanfaatkan segala potensi yang dimilikinya dan mendaya gunakan alam sekitarnya. Inilah hal yang mendasari cerminan kehidupan nelayan Bugis yang tidak lepas dalam sendi-sendi kehidupannya bernafaskan kesyukuran, mereka melihat laut adalah sebagai sumber rezeki yang Allah berikan kepada mereka. 
Adapun apa yang dilakukan oleh masyarakat Wiritasi pada khususnya dan masyarakat Tanah Bumbu pada umumnya ini juga sejalan dengan apa yang dimaksud didalam tri pusat pendidikan terutama pada masyarakat, dimana didalam kehidupan sosial masyarakat tersebut terdapat sebuah norma-norma sosial budaya yang harus diikuti oleh warganya dan norma-norma itu berpengaruh dalam pembentukan kepribadian warganya dalam bertindak dan bersikap sehingga tradisi yang mereka lakukan sampai saat ini sedikit tidaknya mempunyai peran yang cukup penting dalam memberikan pembelajaran dalam memaknai

\section{${ }^{4}$ Batennie, Faisal, "Mappanretasi Terpilih Sebagai Kalender Wisata ASEAN."} Banjarmasin Post, 1 Desember 1991.

Apa yang dilakukan oleh para nenek moyang (generasi tua) terdahulu dalam memberikan bimbingan kepada para penerusnya (generasi muda) melalui tradisi Mappanretasi juga tersirat sebuah tujuan yang sama dengan tujuan pendidikan Islam itu sendiri meskipun dalam perja- lanan tradisi Mappanretasi ada beberapa hal yang harus diluruskan dalam pemahaman dan pengaflikasiannya, yang jelas diharapkan sedikit tidaknya apa yang terkandung pada tradisi Mappanretasi tersebut bisa terwarisi bagi para generasi mudanya. Pesan dari tradisi lisan berupa pesan-pesan lisan yang diucapkan, dinyanyikan atau disebutkan hanya dengan alat musik. Lebih lanjut Vansina menyatakan, bahwa tradisi lisan adalah sebuah bukti yang menerangkan masa lampau pada masyarakat yang belum mengenal aksara. Pandangan dari Vasina diperkuat oleh Thomson (2012: 8), bahwa sejarah lisan setua sejarah itu sendiri, karena ia jenis pertama sejarah. Pandangan Vasina dan Thomson merujuk dari karya Herodotus (bapak sejarah). Herodotus sebagai pionir dalam menulis sejarah melakukan pencarian sumber sejarah dengan melakukan wawancara dengan anak dan cucu dari para pelaku perang antara Yunani dan Parsi. Dalam arti lain, muasal karya sejarah dibangun dari sumber tradisi lisan. Merupakan kewajaran jika Vansina mempunyai anggapan, bahwa tradisi lisan setua dengan penulisan awal sejarah.

\footnotetext{
${ }^{5}$ Anis, M. Z. A. (2015). Sejarah Bukan Warisan Melainkan Pembelajaran FKIP ULM.
} 


\section{A. KESIMPULAN}

Tujuan diadakannya tradisi Mappanretasi adalah merupakan manifestasi rasa syukur masyarakat desa Wiritasi khususnya para Nelayan kepada Allah Swt akan hasil tangkapan ikan selama satu tahun. Kemudian dibalik setiap prosesi ritual tradisi ini (sebelum acara puncaknya Mappanretasi) juga mempunyai tujuan untuk memperoleh solidaritas sosial, menjalin silaturahmi antara warga, agar desa menjadi tentram, sejahtera, harmoni dengan menjaga dan merawat lingkungan hidup melalui cara-cara ritual-ritual keagamaan yang mengandung nilai-nilai kearifan lokal. Dalam proses pelaksanaan tradisi Manppanretasi (acara puncaknya) terlebih dahulu dimulai dengan beberapa rangkaian ritual adat yaitu, (a) mengadakan Mappammulagau Mappanretasi (musyawarah Map- panretasi), (b) ritual Maddemme Berre (merendam beras), (c)Mallibu Wanuwa (mengelilingi daerah), (d) Prosesi Adat di Panggung Adat, (e) syukuran dan selamatan di laut (acara puncak 'Mappanretasi').

Adapun ritual yang tidak sesuai dengan nilai-nilai pendidikan dan tidak perlu digunakan pada masa sekarang salah satu diantaranya yaitu: Pertama, Masih adanya diperdapati beberapa sesajen yang terkadang dihubung- hubungkan dengan sesuatu yang berbau mistis, apabila hal tersebut dibuang, dikhawatirkan akan terjadi musibah atau bencana. Seperti penyembelihan ayam, emas, perak pada mulanya adalah memang ditujukan kepada penguasa laut.

\section{B. SARAN}

Adapun saran saya sebagai penulis artikel sederhana ini berharap sebuah saran dan kritik yang bersifat membangun demi kesempurnaan artikel ini untuk kedepan nya lagi suatu ilmu yang berguna ditambah dengan informasi terbaru mengenai tradisi sejarah kebudayaan mappanretasi yang berbeda dengan sebelumnya karena sanggat berguna semoga artikel ini bisa menambah wawasan baru dalam pembelajaran sejarah serta mendapatkan informasi kita dalam sebuah tradisi sejarah kebudayaan mappanretasi suku Bugis yang bertempat ditanah bumbu kita sebagai generasi muda harus banyak mengetahui tentang sejarah lokal kita sendiri. 


\section{DAFTAR PUSTAKA}

Afifuddin dan Beni Ahmad Saebani, Metodologi Penelitian Kualitatif, Bandung, Pustaka Setia, Cet ke-1, 2009.

Ahmadi, Abu dan Nur Uhbiyati, Ilmu Pendidikan. Jakarta, Rineka Cipta,Cet ke-2, 2001.

Batennie, Faisal, "Mappanretasi Terpilih Sebagai Kalender Wisata ASEAN." Banjarmasin Post, 1 Desember 1991.

"Kerajaan Tanah Bumbu dan Pulau Laut, sub Kerajaan Pagatan." http//faisalbatennie.blogspot.com/2010/07kerajaan-di-tanah bumbu ,html (diakses, pada tanggal 16 Oktober 2021, Jam 20.00 WITA bertempat dibanjarmasin Kalimantan Selatan

Anis, M. Z. A. (2021). Kontrak dan Laporan Penelitian-Pembelajaran Sejarah Kritis Melalui Model Pembelajaran Berpikir Historis (MPBH) Berbasis Issue Centered History dalam Mata Kuliah Sejarah Eropa Pada Program Studi Pendidikan Sejarah FKIP Universitas Lambung Mangkurat (Rp. 24.500. 000,-).

Anis, M. Z. A. (2015). Sejarah Bukan Warisan Melainkan Pembelajaran FKIP ULM Banjarmasin.

Mardiani, M. Z. A. A. F. (2021). MEMPERKUAT IDENTITAS NASIONAL MELALUI MODEL PEMBELAJARAN BERPIKIR HISTORIS (MPBH): ANTARA NYATA ATAU SEBUAH ASA?. In Prosiding Seminar Nasional Lingkungan Lahan Basah(Vol. 6, No 03.

Anis, M. Z. A., Sriwati, S., \& Mardiani, F. (2020). SISI ABU-ABU KAUSALITAS DAN EVALUASINYA DALAM PEMBELAJARAN SEJARAH. Jurnal Socius, 9(2), 169-180

R. Syarifuddin et al.,"Upacara Adat Mappanretasi di Pagat- an Kabupaten Tanah Bumbu." Edisi Laporan Kegiatan Upacara Adat Mappanretasi,Dinas Pemuda Olahraga Kebudayaan dan Pariwisata (DISPORBUD-PAR) Tanah Bumbu, 2008.

Ronadinihari, Rasfienora, "Akta Notaris Nomor 8 tentang Pendirian Lembaga Ade' Ogi Tanah Bumbu".Surat Keputusan (SK), Kantor Kesatuan Bangsa dan Politik, Gunung Tinggi: KESBANGPOL, 2008.

Potensi Desa dan Kelurahan". Profil Desa Wiritasi, Kantor Kepala Desa Wiritasi, 2021 Kabupaten Tanah Bumbu.

Metodologi Penelitian Pendidikan. Jakarta, Rineka Cipta, Cet ke-5, 2005. Jakarta Penerbit : Rineka Cipta 